\title{
IN VITRO EXAMINATION THE EFFECTS OF SOME FUNGICIDES ON THE BIOCONTROL AGENT TRICHODERMA HARZIANUM - CONTRIBUTION TO THE COMPATIBILITY IN TOBACCO PRODUCTION
}

\author{
Biljana Gveroska \\ University "St. Kliment Ohridski"-Bitola ,Scientific Tobacco Institute-Prilep, Republic of Nort Macedonia
}

https://doi.org/10.35410/IJAEB.2021.5631

\begin{abstract}
One of the powerful mechanisms of the biocontrol activity of the genus Trichoderma is a tolerance to pesticides, and their synergistic effect with fungicides is also pointed. The use of these properties, in particular, compatibility in specific production conditions would contribute to increasing their efficacy.

The aim of these studies was to determine the influence of the most commonly used active ingredients in tobacco production on the biocontrol agent Trichoderma. hazianum, which is distinguished by its biocontrol activity to numerous pathogenic fungi that cause tobacco diseases.

Effects of fungicides were performed on 12 fungicides currently used in tobacco production and one combination used in recomended concentration. The study wasperformed three times using the medium poisoning method, in five replication of the each variant.

Most of the fungicides (systemic, contact and the combination) showed a strong as well as significant reducing effecton T. harzianum on the fourth day. Only Proplant 722 SL has a moderate reducing effect.

The strong reducing effect of most of the fungicides was completely lost, i.e. on the tenth day they did not affect the development at all.

Folicur EW -250, Top M as well as the combination Top M + Proplant 722 SL show strong reducing effect. Therefore, they are not compatible with $\mathrm{T}$. harzianum at all.

High compatibility has been found in the Proplant 722 SL, Signum 33WG, Armetil M and Agrizole 250-EC, as well as in the contact fungicides Manfil $80 \mathrm{WP}$ and Enervin WG.

The high compatibility of the fungicide after 10 days is a very useful method of application of the biocontrol agent in the fungicidal treatments. Specifically, the BCA can be applied after the expiration of that period, which is actually applicable in practice.

Developing an integrated disease management strategy by combing Trichoderma and fungicides to prevent pathogen from goaling resistance and building up Trichoderma population levels in the soil that will be effective would be the goal in tobacco protection from diseases.
\end{abstract}


Vol. 06, No. 03; 2021

ISSN: $2456-8643$

Keywords: Trichoderma. Hazianum, Fungicide, Active Ingredient, Reducing Effect, Compatibility.

\section{INTRODUCTION}

Fungi of the genus Trichoderma are the most powerful biocontrol agents. They control a wide range of plant pathogens, including fungi, oomycetes, bacteria, and one virus (Harman, 2004, 2006).

The biocontrol activity of several strains of Trichoderma (T. harzianum, T.aureoviride and $T$. hamatum) is also confirmed on the tobacco pathogens (Gveroska, 2013, 2020b).

Fungal plant pathogens are among the most important factors that cause serious losses to agricultural products as well as tobacco. The pathogenic fungi attack different parts of the tobacco plant and cause a various damages. The most common fungal diseases affecting the tobacco in our country, from seedling production to mature leaves are: the damping-off on seedling caused by Rhizoctonia solani and Pythium debarianum, the black shank caused by Phytophthora parasitica var.nicotianae and the brown spot, by Alternaria alternata. Blue mold is the economically most important disease of the tobacco plant caused by Peronospora tabacina Adam, an obligatory plant parasite which is transmitted over long distances by spreading the conidia.

Trichoderma hazianumis the most effective biocontrol agent in control of the pathogenic fungi in tobacco (Gveroska, 2013). It has a particularly strong effect in controlling the soil pathogens, causing agents of the damping off disease in tobacco seedlings (Gveroska, 2017, 2020a). At the same time, Trichoderma hazianum has been found to has the greatest reduction effect on leaf pathogensin tobacco (Gveroska, 2012).

Beside the great efforts to introduce biological control in tobacco protection, tobacco producers favoured fungicides for managing the crop diseases because of their quick effect, especially in the higher intensity of the disease, even they know their deleterious effect on the product, human health and the environment at whole.

Therefore, the effect of fungicides to the biocontrol agents should be considered and hence, the application of biocontrol agents in integrated protectionof tobacco against diseases has to be strenghteened.

Worldwide investigations of these biocontrol agents, as well as their numerous properties, highlight tolerance for pesticides. Trichoderma species develop very quickly because they are naturally resistant to many toxic components including fungicides, herbicides and various pesticides. They have the ability to rehabilitate quickly despite a subtle dose of pesticides. All this strengthen their powerin biocontrol (Benitez et al., 2004). De Schutter et al.(2002) estimated that in field condition there was no effect of the fungicide treatment on the presence of the fungus (opposite than laboratory experiment). Trichoderma are extremly well adapted to soil, can produce lytic enzymes, antibiotics and/or secondary metabolites and rapidly colonize the soil and rhizosphere, so these features may enhance their abbility to tolerate pesticides in vivo (Franco da Silva et al., 2018)

Therefore, knowledge of the effefct of the fungicides on the biocontrol agent Trichoderma as the permanent member of the plant's immediate environment would allow the proper use of the fungicides, increase the qualityof the crop protection from the disease and improve the integrated management systems. To develop an effective disease management 
Vol. 06, No. 03; 2021

ISSN: $2456-8643$

programme, the compatibility of potential bioagent with fungicides and botanicals is essential (Tapwai et al., 2012). Integration of compatible bioagent with pesticides may enhance the effectiveness of disease control and provide better management of soil borne diseases.

Integration of chemical and bio-agents has been the subject of research during recent years. According to Gowdar et al. (2006), integrated fungicide resistant antagonists with suitable fungicidal treatment has importance in the framework of integrated disease management. There are integrated protection strategies based on the combined application of biological control agents with chemical protection (with a reduced dose of pesticide to the subcutaneous). The effect is greater than when applying individual treatments (Lorito et al., 2009).

Effective integrated management system largely depends on the compatibility of the biocontrol agent with other applied chemicals. To be integrated into a management system, the biocontrtol agent must be compatible with other management practices. Thoudam and Dutta (2014) with the in vitro study examinated the compatibility of Trichoderma atroviride with seven fungicides to control letuce drop. Tapwai et al. (2012) conducted the test of possibility to combining Trichoderma viride with fungicides and botanicals.

Franco da Silva (2018) examinated iprodione and procymidone against letuce drop, pencycuron to control bottom rot caused by $R$. solani, azoxystrobin to control leaf spot (Septoria lactucae) and manipropamid against downy mildew (Bremia lactucae).

De Schutter et al.(2002) conducted experient to evaluate the growth of Trichoderma asperellum in the presence of active ingredients- propamocarb (fungicide Previcur), carbendazim +diethofencarb (Sumico) and carbendazim in three concentracion (10x of dose recommended, also) in which the funguswas totally inhibited by three Sumico and carbandazim concentrations.Manadhar et al. (2020) performed such studies with thirteen used chemical pesticides.

Gowdar et al. (2006) with the laboratory experiment tested the possibility of combining Trichoderma harzianumwith fungicides for seed treatment against soilborne diseases.

Wedajo (2015) made in vitro screening of T. harzianum and T. viride for tolerance to curzate and sancozeb and estimated that both species were well tolerated both fungicides in lower concentration. By increasing the concentration they tolerate to some extent and reduced slightly at higher concentration. Between fungi, T. harzianum was more sensitive than T. viride by both fungicide.

Sarkar et al. (2010) have tested the in vitro effect of fungicides, insecticides and biopesticides on mycelial growth of $T$. harzianum. Seven systemic fungicides, 2 contact fungicides and 4 biopesticides were testedand a varying level of inhibition was observed.

The effective use of biocontrol agent inconventional production requires knowing their compatibility with the most common pesticides applied in this crop (Franco da Silva et al., 2018). Herbicides introduced into the environment influence on non-pathogenic soil microflora and also on the antagonistic fungiTrichoderma (Islami et al.,2008). Based on this, the investigations for their usage in the practice of herbicide application in tobacco seedlings production have been previously performed (Gveroska, 2015).

Keeping the above in view, these studies has the aim to determine the influence of the most commonly used active ingredients in tobacco production on the biocontrol agent $T$. harzianum. 
The obtained results could be used in guidelines for the application of Trichoderma in tobacco protection from diseases. The most importantly, it will create an aplication model of this biocontrol agent with the use of fungicides in tobacco production. Especially, the use of the proper interval of its application or alternation of fungicides with the biocontrol agent, which will achieve a greater effect in the protection against various diseases.

\section{MATERIAL AND METHODS}

The pure culture of T. harzianum is from a collection of pure cultures owned by the Scientific Tobacco Institute-Prilep. This BCA from the genus Trichoderma is selected due to the highly expressed bio-control efficacy of several pathogens of tobacco.

Effects of fungicides were performed on 12 fungicides and one combination (used in seedling production). The selection of preparations included the most commonly used fungicides in tobacco production for control of leaf and soil pahogens. Two of them are contact, and the majority are systemic fungicides. They are investigated in concentration mostly used or recommened(Table 1).

The effect of tested fungicides was estimated using medium poisoning method. Potato Dexstrose Agar (PDA) was used, adding the fungicides after cooling the sterilized medium (20 $\mathrm{ml} /$ Petri dishes, diameter $110 \mathrm{~mm}$ ). Fungicides was in commonly used concentration (for practical application) and added in the medium. PDA inoculated with Trichoderma without fungicide is used as control.Mycelial plugs of $5 \mathrm{~mm}$ of the fungal culture are aseptically placed in the center of medium with fungicides as well as in the control.

\section{Table 1. Tested fungicides}

\begin{tabular}{|c|c|c|}
\hline Fungicide & Active ingredient / s & Concentration $(\%)$ \\
\hline Top-M 70\%WP & $70 \%$ thiophanate - methyl & $0,1 \%$ \\
\hline Proplant $722 \mathrm{SL}$ & $722 \mathrm{~g} / 1$ propamocarb & $0,15 \%$ \\
\hline $\begin{array}{l}\text { Top } \mathrm{M}+ \\
\text { Proplant } 722 \mathrm{SL} \\
\end{array}$ & $\begin{array}{l}70 \% \text { thiophanate }- \text { methyl }+ \\
722 \mathrm{~g} / 1 \text { propamocarb }\end{array}$ & $0,1 \%+0,15 \%$ \\
\hline Manfil 80WP & $800 \mathrm{~g} / \mathrm{kg}$ mancozeb & $0,25 \%$ \\
\hline Enervin WG & $120 \mathrm{~g} / \mathrm{kg}$ ametoctradin + & $0,2 \%$ \\
\hline Orvego $^{\mathrm{TM}}$ & $300 \mathrm{~g} / \mathrm{l}$ ametoctradin + & $0,1 \%$ \\
\hline Signum $33 \mathrm{WG}$ & $\begin{array}{l}267 \mathrm{~g} / \mathrm{kg} \text { boscalid }+ \\
67 \mathrm{~g} / \mathrm{kg} \text { nvraclostrobin }\end{array}$ & $0,15 \%$ \\
\hline Quadris 25 SC & $250 \mathrm{~g} / 1$ azoxystrobin & $0,15 \%$ \\
\hline Armetil M & $8 \%$ metalaxyl $+64 \%$ mancozeb & $0,3 \%$ \\
\hline
\end{tabular}




\begin{tabular}{|l|l|l|}
\hline Galben M & $8 \%$ benalaxyl $+65 \%$ mancozeb & $0,25 \%$ \\
\hline Acrobat MZ WG & $\begin{array}{l}9 \% \text { dimetomorph }+60 \% \\
\text { mannozoh }\end{array}$ & $0,25 \%$ \\
\hline Folicur EW-250 & tebuconazole $250 \mathrm{~g} / l$ & $0,1 \%$ \\
\hline Agrizole 250 EC & difenoconazole $250 \mathrm{~g} / l$ & $0,05 \%$ \\
\hline
\end{tabular}

Inoculated Petri dishes were incubated 10 days on $25^{\circ} \mathrm{C}$. The growth of Trichoderma was determined by daily measuring diameter of the mycelia in two perpendicular directions of each culture plate. Five replications - 5 Petri dishes fot the each variants were used per experiment. The study was replicated three times.

The average values were used in the presentation of results.

The growth reduction of fungicides on T. harzianum (using average values)was calculated according to the formula ofMishra (2010):

$L=\frac{\mathrm{C}-\mathrm{T}}{\mathrm{C}} \times 100$

where $L=$ percentage of inhibition; $\mathrm{C}=$ radial growth of Trichoderma in control; $\mathrm{T}=$ radial growth of Trichoderma in the presence of fungicide.

According to the veryfast development of Trichoderma, reducing effect is calculated on the $4^{\text {th }}$ day (fulfillment of the entire Petri dish), as well as on the end of investigations.

Reducing effect and Index of compatibility were determined according to the scale:

\begin{tabular}{|lllll|}
\hline $\begin{array}{l}\text { Percentage of the } \\
\text { growth reduction }\end{array}$ & Reducing effect & \multicolumn{3}{l|}{ Compatibility } \\
\hline 0 & No reduccing effect & 0 & High compatibility & 5 \\
$0,5-5 \%$ & Insignificant & 1 & Significant & 4 \\
$6-15 \%$ & Weak & 2 & Moderate & 3 \\
$16-50 \%$ & Moderate & 3 & Weak & 2 \\
$51-70 \%$ & Significant & 4 & Insignificant & 1 \\
$71-100 \%$ & Strong reducing effect & 5 & No compatibility & 0 \\
\hline
\end{tabular}

\section{RESULTS AND DISCUSSION}

The biocontrol agent $T$. harzianum begins its intensive development with $18.50 \mathrm{~mm}$ on the first day and completely fills the petri dish on the $5^{\text {th }}$ day of the incubation (Table 2). The tested fungicides have a reducing effect on the development of the biocontrol agent from the first day 
Vol. 06, No. 03; 2021

ISSN: $2456-8643$

of study (except Proplant 722 SL). On the second day, development is noticeable and it continues until the end of the examination. However, at the moment when the biocontrol agent reached its maximum development, i.e. on the $5^{\text {th }}$ day, the diameter of the colony on a medium with the fungicide Galben $\mathrm{M}$ is only $22.00 \mathrm{~mm}$.

The fungus grows most intensively on a substrate with Proplant 722 SL, where the diameter reaches the same value (filling of the petri box) as that of the control (only after one day i.e. on the $6^{\text {th }}$ day). Orvego also showed a slight reducing effect - the diameter is $64 \mathrm{~mm}$. However, at the end of the test the value of the biocontrol agent colony diameter is the same as that of the control $-110 \mathrm{~mm}$ ). This value is reached the fastest with the fungicide Armetil $\mathrm{M}$ and Agrizole 250-EC (on the 8th day). In the fungicide Acrobat MZ WG the fungus shows initial development on the third day but it reaches maximum development as well as in the contact fungicides.

The fungus did not develop during the test on the medium with fungicides Top-M 70\% WP, Folicur EW-250 and the combination Top M + Proplant 722 SL (Table 2).

Table 2. Development of the colony of $T$. harzianum- $1^{\text {st }}$ replication

\begin{tabular}{|c|c|c|c|c|c|c|c|c|c|c|}
\hline day & 1 & 2 & 3 & 4 & 5 & 6 & 7 & 8 & 9 & 10 \\
\hline $\begin{array}{l}\text { Variant } \\
\text { (fungicide) }\end{array}$ & \multicolumn{10}{|c|}{ Diameter in $\mathrm{mm}$} \\
\hline Top M $0,1 \%$ & - & - & - & - & - & - & - & - & - & - \\
\hline $\begin{array}{l}\text { Proplant } 722 \text { SL } \\
0,15 \%\end{array}$ & $\begin{array}{l}17,2 \\
0\end{array}$ & 47,20 & 64,70 & 87,40 & $\begin{array}{l}105,0 \\
0\end{array}$ & $\begin{array}{l}110,0 \\
0\end{array}$ & $\begin{array}{l}110,0 \\
0\end{array}$ & $\begin{array}{l}110,0 \\
0\end{array}$ & $\begin{array}{l}110,0 \\
0\end{array}$ & $\begin{array}{l}110,0 \\
0\end{array}$ \\
\hline $\begin{array}{l}\text { Top M } 0,1 \%+ \\
\text { Proplant } 722 \text { SL } \\
0,15 \%\end{array}$ & - & - & - & - & - & - & - & - & - & - \\
\hline $\begin{array}{lll}\text { Manfil } & 80 & \text { WP } \\
0,25 \% & & \end{array}$ & - & - & 5,20 & 36,60 & 46,80 & 77,20 & 95,40 & $\begin{array}{l}109,2 \\
0\end{array}$ & $\begin{array}{l}110,0 \\
0\end{array}$ & $\begin{array}{l}110,0 \\
0\end{array}$ \\
\hline $\begin{array}{ll}\text { Enervin } & \text { WG } \\
0,2 \% & \end{array}$ & - & 10,40 & 20,20 & 33,40 & 67,70 & 89,70 & 92,00 & $\begin{array}{l}105,0 \\
0\end{array}$ & $\begin{array}{l}110,0 \\
0\end{array}$ & $\begin{array}{l}110,0 \\
0\end{array}$ \\
\hline $\begin{array}{l}\text { Signum } 33 \mathrm{WG} \\
0,1 \%\end{array}$ & - & 11,60 & 31,80 & 53,40 & 66,00 & 79,60 & 93,20 & $\begin{array}{l}108,0 \\
0\end{array}$ & $\begin{array}{l}110,0 \\
0\end{array}$ & $\begin{array}{l}110,0 \\
0\end{array}$ \\
\hline Orvego $0,1 \%$ & - & 17,60 & 44,00 & 64,00 & 80,40 & 92,00 & 98,00 & $\begin{array}{l}103,8 \\
0\end{array}$ & $\begin{array}{l}110,0 \\
0\end{array}$ & $\begin{array}{l}110,0 \\
0\end{array}$ \\
\hline $\begin{array}{l}\text { Quadris } 25 \quad \text { SC } \\
0,15 \%\end{array}$ & - & 2,00 & 10,80 & 28,60 & 33,30 & 40,00 & 42,80 & 53,70 & 74,70 & 82,90 \\
\hline
\end{tabular}


International Journal of Agriculture, Environment and Bioresearch

Vol. 06, No. 03; 2021

ISSN: $2456-8643$

\begin{tabular}{|l|l|l|l|l|l|l|l|l|l|l|}
\hline Armetil M & - & - & 15,00 & 43,60 & 63,30 & 92,60 & 105,0 & 110,0 & 110,0 & 110,0 \\
\hline Galben M 0,25\% & - & 5,20 & 18,00 & 22,00 & 35,00 & 47,60 & 59,40 & 71,60 & 78,00 & 84,00 \\
\hline $\begin{array}{l}\text { Acrobat MZ WG } \\
0,25 \%\end{array}$ & - & - & 15,60 & 42,70 & 64,30 & 85,20 & $\begin{array}{l}101,0 \\
0\end{array}$ & $\begin{array}{l}108,0 \\
0\end{array}$ & $\begin{array}{l}110,0 \\
0\end{array}$ & $\begin{array}{l}110,0 \\
0\end{array}$ \\
\hline $\begin{array}{l}\text { Agrizole 250-EC } \\
0,05 \%\end{array}$ & - & 5,40 & 15,40 & 39,40 & 57,00 & 76,00 & 96,60 & $\begin{array}{l}110,0 \\
0\end{array}$ & $\begin{array}{l}110,0 \\
0\end{array}$ & $\begin{array}{l}110,0 \\
0\end{array}$ \\
\hline $\begin{array}{l}\text { Folicur EW -250 } \\
01 \%\end{array}$ & - & - & - & - & - & - & - & - & - & - \\
\hline Check $\varnothing$ & 18,8 & 53,40 & 90,20 & $\begin{array}{l}105,3 \\
0\end{array}$ & $\begin{array}{l}110,0 \\
0\end{array}$ & $\begin{array}{l}110,0 \\
0\end{array}$ & $\begin{array}{l}110,0 \\
0\end{array}$ & $\begin{array}{l}110,0 \\
0\end{array}$ & $\begin{array}{l}110,0 \\
0\end{array}$ & $\begin{array}{l}110,0 \\
0\end{array}$ \\
\hline
\end{tabular}

In the second replication the test, the bicontrol agent reached its maximum development earlier, on the fourth day. The situation with fungicides is similar to the first replication. Although the initial development is weakest in contact fungicides, the final diameter reaches 110 $\mathrm{mm}$ (Table 3). But that value is also reached on the medium with the systemic fungicides Signum 33 WG, OrvegoTM, Armetil M and Folicur EW-250. The greatest reducing effect has the fungicide Quadris $25 \mathrm{SC}$ where the fungus reached a growth of $67.80 \mathrm{~mm}$. Galben $\mathrm{M}$ $(81.80 \mathrm{~mm})$ has a similar effect.

In the third replicationthe control reached full development on the fourth day,as before. The development of the fungus was not observed in the same fungicides. On the $4^{\text {th }}$ day, the smallest diameter was measured in the medium with fungicide Galben M $(12.20 \mathrm{~mm})$. It has $53.20 \mathrm{~mm}$ in Signum and the highest value it has in Proplant $(92.40 \mathrm{~mm})$.

On the 10th day, the smallest value of the diameter is $81.00 \mathrm{~mm}$ in Galben and $94.30 \mathrm{~mm}$ in Quadris. Although the fungus develops fromthe first day in the medium with Orvego, the diameter reached a slightly lower value (Table 4).

Analyzing the results as the mean value of the replications (Table 5), the same situiation can be determined. At the moment when the biocontrol agent reached the maximum value in the control on the 4th day, it has reached the smallest diameter in the medium with the fungicide Galben M, and the largest with the fungicide Proplant 722 SL.

Galben M maintained this effect until the end of the study and the biocontrol agent has the smallest colony diameter $(81.67 \mathrm{~mm})$. The effect is similar in the Quadris $25 \mathrm{SC}(82.27 \mathrm{~mm})$. 
Vol. 06, No. 03; 2021

ISSN: $2456-8643$

Table 3. Development of the colony of $T$. harzianum $-2^{\text {nd }}$ replication

\begin{tabular}{|l|l|l|l|l|l|l|l|l|l|l|l|}
\hline \multicolumn{2}{|l|}{ day } & 1 & 2 & 3 & 4 & 5 & 6 & 7 & 8 & 9 & 10 \\
\cline { 2 - 11 } \\
(fungicide)
\end{tabular}


Table 4. Development of the colony of $T$. harzianum $-3^{\text {rd }}$ replication

\begin{tabular}{|c|c|c|c|c|c|c|c|c|c|c|}
\hline \multirow{2}{*}{ Variant } & 1 & 2 & 3 & 4 & 5 & 6 & 7 & 8 & 9 & 10 \\
\hline & \multicolumn{10}{|c|}{ Diameter in $\mathrm{mm}$} \\
\hline Top M $0,1 \%$ & - & - & - & - & - & - & - & - & - & - \\
\hline $\begin{array}{l}\text { Proplant } 722 \text { SL } \\
0,15 \%\end{array}$ & $\begin{array}{l}21,6 \\
0\end{array}$ & 44,70 & 76,80 & 92,40 & $\begin{array}{l}104,0 \\
0\end{array}$ & $\begin{array}{l}110,0 \\
0\end{array}$ & $\begin{array}{l}110,0 \\
0\end{array}$ & $\begin{array}{l}110,0 \\
0\end{array}$ & $\begin{array}{l}110,0 \\
0\end{array}$ & $\begin{array}{l}110,0 \\
0\end{array}$ \\
\hline $\begin{array}{l}\text { Top M } 0,1 \%+ \\
\text { Proplant } 722 \text { SL } \\
0,15 \%\end{array}$ & - & - & - & - & - & - & - & - & - & - \\
\hline $\begin{array}{lll}\text { Manfil } & 80 & \text { WP } \\
0,25 \% & & \end{array}$ & - & 2,20 & 10,20 & 24,40 & 48,30 & 77,80 & 78,00 & 96,00 & $\begin{array}{l}104,6 \\
0\end{array}$ & $\begin{array}{l}110,0 \\
0\end{array}$ \\
\hline $\begin{array}{l}\text { Enervin } \quad \mathrm{WG} \\
0,2 \%\end{array}$ & - & 5,80 & 13,40 & 36,00 & 64,22 & 89,27 & 91,80 & $\begin{array}{l}110,0 \\
0\end{array}$ & $\begin{array}{l}110,0 \\
0\end{array}$ & $\begin{array}{l}110,0 \\
0\end{array}$ \\
\hline $\begin{array}{l}\text { Signum } 33 \mathrm{WG} \\
0,1 \%\end{array}$ & - & 11,60 & 23,20 & 53,20 & 73,40 & 89,60 & $\begin{array}{l}100,0 \\
0\end{array}$ & $\begin{array}{l}110,0 \\
0\end{array}$ & $\begin{array}{l}110,0 \\
0\end{array}$ & $\begin{array}{l}110,0 \\
0\end{array}$ \\
\hline Orvego $0,1 \%$ & 7,60 & 12,60 & 24,80 & 36,00 & 46,40 & 57,60 & 67,00 & 80,40 & 98,00 & $\begin{array}{l}108,0 \\
0\end{array}$ \\
\hline $\begin{array}{lll}\text { Quadris } & 25 & \mathrm{SC} \\
0,15 \% & & \end{array}$ & - & 10,00 & 16,60 & 29,30 & 34,70 & 58.71 & 74,40 & 81,80 & 86,90 & 94,30 \\
\hline Armetil M & - & - & 20,80 & 33,80 & 53,00 & 72,40 & 93,00 & 100,4 & 110,0 & 110,0 \\
\hline Galben M 0,25\% & - & 5,60 & 6,80 & 12,20 & 26,40 & 40,70 & 45,60 & 58,40 & 74,40 & 81,00 \\
\hline $\begin{array}{l}\text { Acrobat MZ WG } \\
0,25 \%\end{array}$ & - & - & 14,80 & 21,60 & 36,20 & 50,00 & 69,40 & 97,80 & $\begin{array}{l}110,0 \\
0\end{array}$ & $\begin{array}{l}110,0 \\
0\end{array}$ \\
\hline $\begin{array}{l}\text { Agrizole } 250 \text {-EC } \\
0,05 \%\end{array}$ & - & 5,40 & 19,39 & 39,40 & 57,33 & 74,89 & 96,00 & $\begin{array}{l}108,1 \\
0\end{array}$ & $\begin{array}{l}110,0 \\
0\end{array}$ & $\begin{array}{l}110,0 \\
0\end{array}$ \\
\hline $\begin{array}{l}\text { Folicur EW }-250 \\
01 \%\end{array}$ & - & - & - & - & - & - & - & - & - & - \\
\hline Check $\varnothing$ & $\begin{array}{l}16,6 \\
0\end{array}$ & 50,20 & 90,20 & $\begin{array}{l}110,0 \\
0\end{array}$ & $\begin{array}{l}110,0 \\
0\end{array}$ & $\begin{array}{l}110,0 \\
0\end{array}$ & $\begin{array}{l}110,0 \\
0\end{array}$ & $\begin{array}{l}110,0 \\
0\end{array}$ & $\begin{array}{l}110,0 \\
0\end{array}$ & $\begin{array}{l}110,0 \\
0\end{array}$ \\
\hline
\end{tabular}




\section{International Journal of Agriculture, Environment and Bioresearch}

Vol. 06, No. 03; 2021

ISSN: $2456-8643$

The results in Table 5 in relation to the fungicide Proplant $722 \mathrm{~S} 1$ confirm the previous findings - the fungus grows the best, i.e.this fungicide has the insignificant or no reducing effect. Systemic fungicides Top M and Folicur EW-250 showed a strong reducing effect. The influence of the first mentioned is also expressed in the combination Top $\mathrm{M}+$ Proplant, i.e. there is no development of T. harzianum. In other systemic fungicides Signum, Armetil and Agrizole the fungus still reached the same value as in the control (Table 5).

Analyzing the contact fungicides, it can be noticed that Enervin WG in the three replications has a slightly smaller reducing effect compared to Manfil 80WP. The initial development is bigger, but the maximum value is reached one day earlier than in Manfil 80WP.

Table 5. Development of the colony of $T$. harzianumin the presence of fungicides (average value of 3 replications)

\begin{tabular}{|c|c|c|c|c|c|c|c|c|c|c|}
\hline \multirow{2}{*}{$\begin{array}{l}\text { day } \\
\text { Variant } \\
\text { (fungicide) }\end{array}$} & 1 & 2 & 3 & 4 & 5 & 6 & 7 & 8 & 9 & 10 \\
\hline & \multicolumn{10}{|c|}{ Diameter in $\mathrm{mm}$} \\
\hline Top M $0,1 \%$ & - & - & - & - & - & - & - & - & - & - \\
\hline $\begin{array}{l}\text { Proplant } 722 \text { SL } \\
0,15 \%\end{array}$ & $\begin{array}{l}18,2 \\
7\end{array}$ & 45,03 & 75,77 & 90,77 & $\begin{array}{l}105,1 \\
3\end{array}$ & 110,00 & $\begin{array}{l}110,0 \\
0\end{array}$ & $\begin{array}{l}110,0 \\
0\end{array}$ & $\begin{array}{l}110,0 \\
0\end{array}$ & $\begin{array}{l}110,0 \\
0\end{array}$ \\
\hline $\begin{array}{l}\text { Top M } 0,1 \%+ \\
\text { Proplant } 722 \text { SL } \\
0,15 \%\end{array}$ & - & - & - & - & - & - & - & - & - & - \\
\hline $\begin{array}{lll}\text { Manfil } & 80 & \text { WP } \\
0,25 \% & & \end{array}$ & - & + & 7,53 & 29,07 & 48,27 & 77,53 & 88,80 & $\begin{array}{l}104,8 \\
7\end{array}$ & $\begin{array}{l}108,2 \\
0\end{array}$ & $\begin{array}{l}110,0 \\
0\end{array}$ \\
\hline $\begin{array}{ll}\text { Enervin } & \text { WG } \\
0,2 \% & \end{array}$ & - & 7,33 & 15,67 & 35,13 & 65,61 & 89,42 & 91,87 & $\begin{array}{l}108,3 \\
3\end{array}$ & $\begin{array}{l}110,0 \\
0\end{array}$ & $\begin{array}{l}110,0 \\
0\end{array}$ \\
\hline $\begin{array}{l}\text { Signum } 33 \mathrm{WG} \\
0,1 \%\end{array}$ & - & 11,60 & 26,07 & 53,27 & 71,60 & 86,27 & 97,73 & $\begin{array}{l}108,6 \\
7\end{array}$ & $\begin{array}{l}110,0 \\
0\end{array}$ & $\begin{array}{l}110,0 \\
0\end{array}$ \\
\hline Orvego $0,1 \%$ & +- & 15,15 & 33,93 & 48,70 & 66,03 & 77,80 & 83,80 & 95,10 & $\begin{array}{l}106,0 \\
0\end{array}$ & $\begin{array}{l}109,3 \\
3\end{array}$ \\
\hline $\begin{array}{lll}\text { Quadris } & 25 & \mathrm{SC} \\
0,15 \% & & \end{array}$ & - & + & 15,47 & 28,90 & 33,20 & 48,30 & 56,27 & 63,37 & 73,40 & 82,27 \\
\hline Armetil M & - & + & 23,53 & 43,47 & 63,00 & 86,47 & 100,1 & 106,4 & 110,0 & 110,0 \\
\hline Galben M 0,25\% & - & + & 13,60 & 20,20 & 32,07 & 44,17 & 53,33 & 63,47 & 74,60 & 81,67 \\
\hline
\end{tabular}


International Journal of Agriculture, Environment and Bioresearch

Vol. 06, No. 03; 2021

ISSN: $2456-8643$

\begin{tabular}{|l|l|l|l|l|l|l|l|l|l|l|}
\hline $\begin{array}{l}\text { Acrobat MZ WG } \\
0,25 \%\end{array}$ & - & - & 11,27 & 29,37 & 45,10 & 62,00 & 80,80 & 96,80 & $\begin{array}{l}105,0 \\
7\end{array}$ & $\begin{array}{l}107,1 \\
3\end{array}$ \\
\hline $\begin{array}{l}\text { Agrizole 250-EC } \\
0,05 \%\end{array}$ & - & + & 18,73 & 39,27 & 57,18 & 75,10 & 96,40 & $\begin{array}{l}107,0 \\
3\end{array}$ & $\begin{array}{l}110,0 \\
0\end{array}$ & $\begin{array}{l}110,0 \\
0\end{array}$ \\
\hline $\begin{array}{l}\text { Folicur EW -250 } \\
01 \%\end{array}$ & - & - & - & - & - & - & - & - & - & - \\
\hline Check $\varnothing$ & 3 & 51,13 & 90,20 & $\begin{array}{l}110,0 \\
0\end{array}$ & $\begin{array}{l}110,0 \\
0\end{array}$ & 110,00 & $\begin{array}{l}110,0 \\
0\end{array}$ & $\begin{array}{l}110,0 \\
0\end{array}$ & $\begin{array}{l}110,0 \\
0\end{array}$ & $\begin{array}{l}110,0 \\
0\end{array}$ \\
\hline
\end{tabular}

The influence of the tested fungicides are shown on Photo 1-7.

The reducing effect of fungicides on T. harzianumis based on the values on day $4^{\text {th }}$, i.e. when the fungus reaches its maximum development. Estimating the influence of the fungicides until the $10^{\text {th }}$ day, the initial negative influence gradually decreases at the end of the examination and the biocontrol agent in some variants reaches high values of the diameter of the colony, i.e. the same as in the control.Reducing effect on the $10^{\text {th }}$ day is a very important parameter for the impactof fungicides. The impact of fungicides - the growth reduction on this biocontrol agent in the incubation period is presented in the Graph 1.

Based on the reducing effect, the compatibility index is presented. Consequently, preparations with a lower reducing effect have greater compatibility and vice versa (Table 6 , Graph 2).

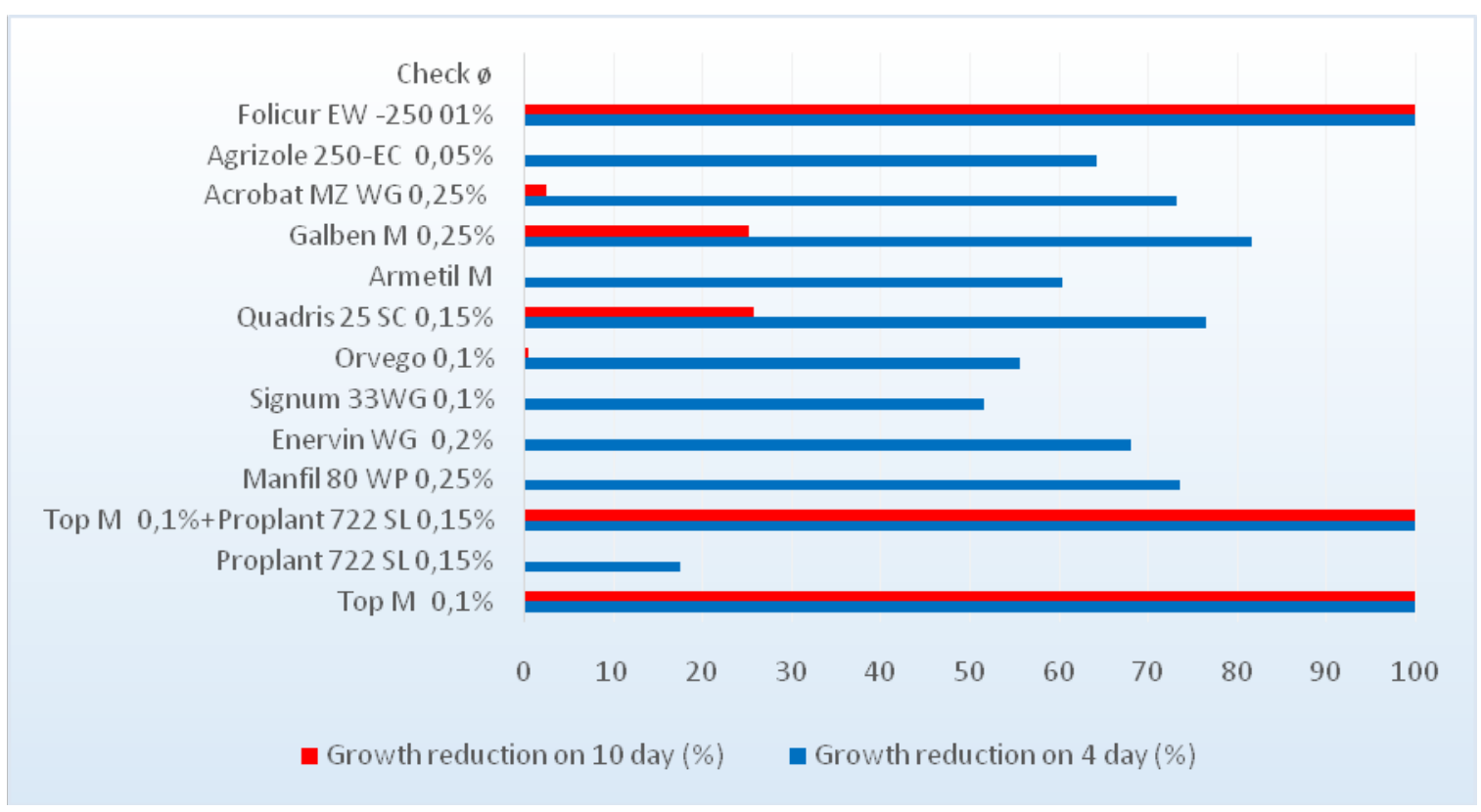

Graph 1. The impact of fungicides on T.harzianum 
Most of the fungicides (as well as the combination Top M + Proplant 722 SL) on the fourth day showed a strong reducing effect on T. harzianum.

Significant reducing effect has been observed inthe systemic fungicides Signum 33WG, Orvego, Armetil M and Agrizole 250-EC. The fungicide Proplant 722 SL has a moderate reducing effect on the biocontrol agent. This effect is manifested from the beginning to the end of the study.

Contact fungicides also showed a strong (Manfil $80 \mathrm{WP}$ ) or significant reducing effect (Enervin WG).

Very noticeable is that on the end of the observation period most of the fungicides have not a negative effect on the biocontrol agent. This conclusion refers to both contact and some systemic fungicides.

It is significant that in most of them the strong reducing effect was completely lost, i.e. on the tenth day they did not affect the development at all. Even in the systemic fungicides Quadris $25 \mathrm{SC}$ and Galben M, the strong reducing effect is reduced to moderate. Significant reduction is lost in Agrizole 250-EC and Armetil M or reduced to insignificant (Orvego and Acrobat MZ).

The strong reducing effect of Folicur EW -250, Top M as well as the combination Top M + Proplant 722 SL is manifested to the end (no colony development is observed at all). Therefore, they are not compatible with T. harzianum at all.

High compatibility has been found in the Proplant 722 SL, Signum 33WG, Armetil M and Agrizole 250-EC, as well as in the contact fungicides Manfil $80 \mathrm{WP}$ and Enervin WG.

The compatibility of these fungicides are important for the correct and timely application of the fungicides and biocontrol agent even in the alternatingapplication with the aim to prevent the reduction of $T$. harzianumpopulation and maintain the quantity this biocontrol agent.

Table 6. Fungicides in tobacco production - reducing effect on the $T$. harzianum and compatibility

\begin{tabular}{|c|c|c|c|c|c|c|c|c|}
\hline \multirow[t]{2}{*}{ Variant (fungicide) } & \multicolumn{2}{|c|}{$\begin{array}{l}\text { Diameter of the } \\
\text { colony } \\
(\mathrm{mm})\end{array}$} & 泀 & 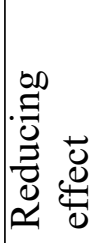 & 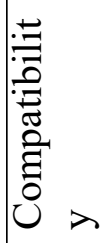 & 造 & 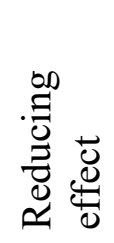 & 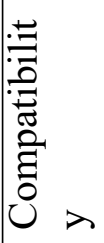 \\
\hline & $\begin{array}{l}4^{\text {th }} \\
\text { day }\end{array}$ & $10^{\text {th }}$ day & \multicolumn{3}{|c|}{$4^{\text {th }}$ day } & \multicolumn{3}{|c|}{$10^{\text {th }}$ day } \\
\hline Top M $0,1 \%$ & - & - & 100 & 5 & 0 & 100 & 5 & 0 \\
\hline $\begin{array}{lll}\begin{array}{l}\text { Proplant } \\
0,15 \%\end{array} & 722 & \text { SL } \\
\end{array}$ & 90,77 & 110,00 & 17,48 & 3 & 2 & 0 & $\mathbf{0}$ & 5 \\
\hline $\begin{array}{l}\text { Top M } 0,1 \%+ \\
\text { Proplant } \quad 722 \quad \text { SL }\end{array}$ & - & - & 100 & 5 & 0 & 100 & 5 & 0 \\
\hline
\end{tabular}


Vol. 06, No. 03; 2021

ISSN: $2456-8643$

\begin{tabular}{|l|l|l|l|l|l|l|l|l|}
\hline $0,15 \%$ & & & & & & & & \\
\hline Manfil 80 WP 0,25\% & 29,07 & 110,00 & 73,57 & 5 & 0 & 0 & $\mathbf{0}$ & $\mathbf{5}$ \\
\hline Enervin WG 0,2\% & 35,13 & 110,00 & 68,06 & 4 & 1 & 0 & $\mathbf{0}$ & $\mathbf{5}$ \\
\hline Signum 33WG 0,1\% & 53,27 & 110,00 & 51,57 & 4 & 1 & 0 & $\mathbf{0}$ & $\mathbf{5}$ \\
\hline Orvego 0,1\% & 48,70 & 109,33 & 55,72 & 4 & 1 & 0,61 & 1 & 4 \\
\hline Quadris 25 SC 0,15\% & 28,90 & 81,67 & 76,45 & 5 & 0 & 25,75 & 3 & 2 \\
\hline Armetil M 0,3\% & 43,47 & 110,00 & 60,48 & 4 & 1 & 0 & $\mathbf{0}$ & $\mathbf{5}$ \\
\hline Galben M 0,25\% & 20,20 & 82,27 & 81,64 & 5 & 0 & 25,78 & 3 & 2 \\
\hline $\begin{array}{l}\text { Acrobat MZ WG } \\
0,25 \%\end{array}$ & 29,37 & 107,13 & 73,30 & 5 & 0 & 2,61 & 1 & 4 \\
\hline $\begin{array}{l}\text { Agrizole 250-EC } \\
0,05 \% \text { (39,27 }\end{array}$ & 110,00 & 64,30 & 4 & 1 & 0 & $\mathbf{0}$ & $\mathbf{5}$ \\
\hline Folicur EW -250 01\% & - & - & 100,00 & 5 & 0 & 100,0 & 5 & 0 \\
\hline Check ø & 110,0 & 110,00 & - & - & - & - & - & - \\
\hline
\end{tabular}

All investigated fungicides in this study showed various reducihg effect to the growth of Trichoderma harzianum. According to Sarkar et al. (2010), effect of some fungicides to the biocontrol agent can be explained in terms of the variation in sensitivity.

In the study of Franco da Silva (2018), azoxystrobin had no effect on the mycelial growth but reduced conidial germination. Conidia of all studied Trichoderma isolates were sensitive to azoxystrobin and no germination was observed at the concentration of $10 \mu \mathrm{g} \mathrm{L}^{-1}$. The isolates showed similar LD values, varying from 0,42 to $0,36 \mu \mathrm{g} \mathrm{L}{ }^{-1}$ azoxystrobin.

Conducted the test of possibility to combining with 5 fungicides and botanicals, Tapwai et al. (2012) founded that $T$. viride is insensitive to Blue coper and Captaf and highly sensitive to Dithane M-45, Bavistin and Ridomil.

Vijayaraghvan and Abraham (2004, loc cit. Wedajo 2015) reported of compatibility of mancozeb with Trichoderma species. The certain complementarity of this statement is in the findings of Raziq and Ishtiaq (2010) who noted the greates reduction of the colony of Alternaria solani caused when the T. harzianum was integrated with Dihane M-45. Therefore, integration of Trichoderma with the lower dose of the fungicides may offer a promissing control of $A$. solani.

But there is some specifity in this study. Reducing effect of Manocozeb is lost at the end of the incubation, so it has a high compatibility. 
Gowdar et al.(2006) were recored maximum inhibition (100\%) with carbendazim followed by 96,8 and $88,44 \%$ in thiophanate-methyl in 0,1 and $0,2 \%$ concentration at $24 \mathrm{hrs}$. incubation. The minimum inhibition $(0,00 \%)$ was observed in captan $(0,1$ and $0,2 \%)$ at 48 and 72 hrs. Thiophanate-methyl showed the strong reducing effect in this study, too.

According to Sarkar et al. (2010), among systemic fungicides, hexaconazole was the most toxic, followed by propiconazole and triflumizole. Toxicity of of the contact fungicides was lower than that of the systemic fungicides. Among the biopesticides, there were a various dergee of toxicity. The mixture of plant extract was compatible with the growth of T. harzianum.

The toxicity effect of tebuconazole was not among the highest. They estimated that azoxystrobin and bitertranol were most compatible with the biocontrol agent. In this study azoxystrobin(Quadris 25SC) did not showed expected results and there is a weak compatibility.

T. asperellum showed a small but significant decrease of growth only in 10x of dose recommended propamocarb. It was totally inhibited by three concentrations of carbendazim +diethofencarb and carbandazim (De Schutter et al., 2002).

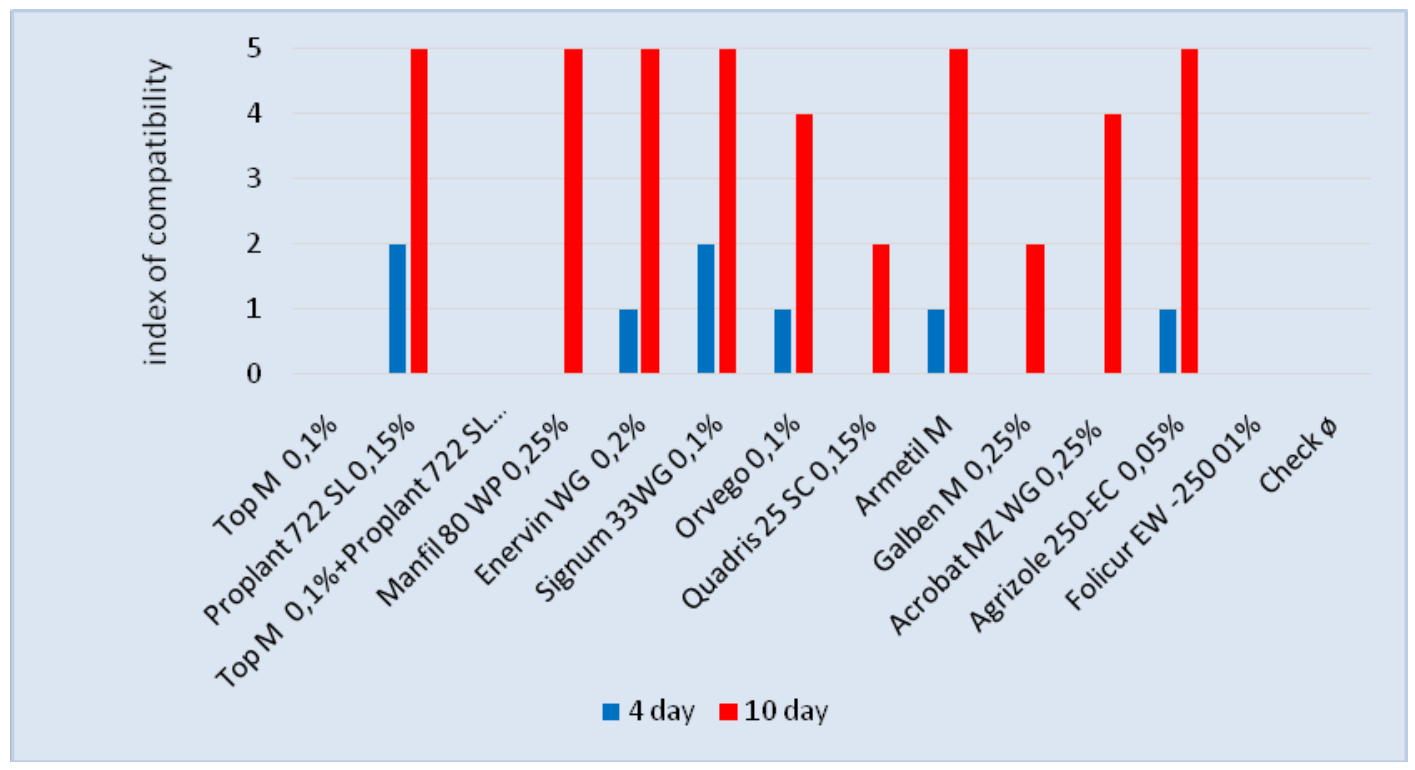

Graph 2. Compatibility of the tested fungicides withT. harzianum

T. harzianum had been shown as highly compatible to propamocarb after the period of four days. By using T. harzianum and T. viridestrains resistant to propamocarb can be control Fusarium using the fact that propamocarbis not active on Fusarium (it acts on Oomycetes). Suppressing them, there are released available carbon and energy (because Oomycetes are a significant part of the mass of fungi in the soil). There is an increase in the population of the biocontrol agent, and thus stronger supppression of the pathogen (Wojtkowiak -Gebarowska and Pjetr, 2006).

The majority of fungicides, contact and systemic, with the expiry of the examination period, reduce or lose the negative impact on the development of this BCA. Gowdar et al. (2006) 
Vol. 06, No. 03; 2021

ISSN: $2456-8643$

also confirmed the decreasing of the percent inhibition of the $T$. harzianum with increasing in incubation period.

The passing the time period to releasing or lowering the reducing effect of the fungicide on the biocontrol agent has made an outstanding contribution to the practice in terms of the interval of its application or alteration with the biocontrol agent.

These reults estimated that there is a high compatibility of the fungicide after 10 days. Hence, it is a very useful method of application of the biocontrol agent in the fungicidal treatments. Specifically, the BCA can be applied after the expiration of that period, which is actually applicable in practice.

Since fungicides have inhibitory effect on the pathogen but should not have deleterious effect on the antagonist, an understanding of the effect of fungicides on the pathogen and antagonist would provide information for the selection of fungicide and fungicide resistant antagonists. In adition, this strategy may display even better control of resistant strains of fungal pathogens and may help the growers to reduce the amount of fungicide use, thus lowering the amount of chemical residue in the market product (Thoudam and Dutta, 2014).

Disease prevention can be increased by using such tolerant species that keeps pathogen under sufficient pressure so that they can not thrive (Wedajo, 2015). Therefore, knowledge of the effefct of the fungicides on the biocontrol agent Trichoderma as the permanent member of the plant's immediate environment would allow the proper use of the fungicides, increase the qualityof the crop protection from the disease and improve the integrated management systems.

Studing the effect of commonly used fungicides on the biocontrol agent $T$. harzianummay offer recommendations for their combined use, the appropriate rate / dose of fungicide used, or the correct choice of fungicide for integrated managementof tobacco diseases. Developing an integrated disease management strategy by combing Trichoderma and fungicides to prevent pathogen from goaling resistance and building upTrichoderma population levels in the soil that will be effective would be the goal in tobacco protection from diseases.

\section{CONCLUSIONS}

- The results of the influence of the investigated fungicides are important for the correct and timely application of the biocontrol agent to prevent the reduction of its population, as well as the choice of fungicide in order to maintain the quantitative presence of this agent.

- Most of the fungicides (systemic, contact and the combination) showed a strong as well as significant reducing effecton T. harzianum on the fourth day.

- The strong reducing effect of most of the fungicides was completely lost, i.e. on the tenth day they did not affect the development at all.

- Folicur EW -250, Top M as well as the combination Top M + Proplant 722 SL show strong reducing effect. Therefore, they are not compatible with $T$. harzianum at all.

- High compatibility has been found in the Proplant 722 SL, Signum 33WG, Armetil M and Agrizole 250-EC, as well as in the contact fungicides Manfil $80 \mathrm{WP}$ and Enervin WG.

- The passing the time period to releasing or lowering the reducing effect of the fungicide on the biocontrol agent has made an outstanding contribution to the practice in terms of the interval of its application or alteration with the biocontrol agent. 
Vol. 06, No. 03; 2021

ISSN: $2456-8643$

- The high compatibility of the fungicide after 10 days allow to aply the biocontrol agent in the fungicidal treatments after the expiration of that period, which is actually applicable in practice.

- Further research is needed to evaluate the most appropriate concentration of fungicide to get the minimum reducing effect of biocontrol agent i.e. compatibility.

- Developing an integrated disease management strategy by combing Trichoderma and fungicides by preventingresistance of pathogen and building up Trichoderma population levels in the soil that will be effective would be the goal in tobacco protection from diseases.

\section{REFFERENCES}

1. Benítez, T., Rincón, M.A., Limón, C.M., Codón, C.A., 2004. Biocontrol mechanisms of Trichoderma strains. International microbiology, Vol 7: 249-260.

2. De Schutter B., Aerts R., Romboust L.,2002. The influence of fungicides on the growth of Trichoderma asperellum. Meded Rijksuniv Gent Fak Landbouwkd Toegep Biol Wet., 67 (2):291-8.

3. Franco da Silva M. A., de Moura K.E., de Moura K.E., Salomao D., Patricio F.R.A., 2018. Compatibility of Trichoderma isolates with pesticides used in lettuce crop. Summa Phytopathol. Botucatu, V.44, n. 2, p.137-142.

4. Gowdar S.B., Babu H.N.R, Nargund V.B., Krishnappa M., 2006. Comapatibility of fungicides with Trichoderma harzianum. Agric. Sci. Digest, 26 (4): 279-281.

5. Gveroska B., Ziberoski J. 2012. Trichoderma harzianum as a biocontrol agent against Alternaria alternata on tobacco. Applied Technologies and Innovations, Volume 7, Issue 2, pp. 67-76, Prague Development Center, Chech Republic.

6. Gveroska B., 2013 In vitro biocontrol activity of Trichoderma harzianum against some pathogenic fungi on tobacco, Food and Environment Safety, Vol XII, Issue 1, pp. 95-104.

7. Gveroska B., 2015.Trichoderma Harzianum in Tobacco Seedlings with the use of a Herbicide International. Journal of Agriculture Innovations and Research, Volume 3, Issue 3, 936-941.

8. Gveroska B., 2017. Toacco seedlings protection from damping off disease with Trichoderma harzianum T22 (Bioproduct TRIANUM P) Tutun / Tobacco Vol. 67, N 7-12, pp. 35-45.

9. Gveroska B.,2020a.Application ofTrichoderma harzianum in tobacco seedlings protection, brochure, Scientific Tobacco Institute-Prilep.

10. Gveroska B.,2020b.Trichoderma biocontrol agents for tobacco seedlings protection. Global studies of tobacco, tobacco products, and innovative nicotine-containing products: status and perspectives, International scientific conference November 17, Federal state budgetary scientific institution all-russian research institute of tobacco, makhorka and tobacco products, Chrasnodar, pp. 55-165

11. Harman G.E., 2004. Trichoderma species-opportunistic avirulent plant symbionts, Nature Review Microbiology Vol 2,pp. 43-56.

12. Harman G.E., 2006. Overview of Mechanisms and Uses of Trichoderma spp, Phytopathology 96, pp. 190-194

13. Lorito M., Woo S.L., Ambrosio M.D., Harman G.E., Hayes C.K., Kubicek C.P., Scala F., 1996. Synergistic Interaction Between Cell Wall Degrading Enzymes and Membrane Affecting Compounds. Molecular Plant-Microbe Interactions. Vol.9, No. 3, pp.206-213. 
Vol. 06, No. 03; 2021

ISSN: 2456-8643

14. Islami M.S., Saha A.K., Mosaddeques H.Q.M., Amin M.R., Islam M.M., 2008. In vitro studies on the reaction of fungi Trichodermato different herbicides used in tea plantation. Int. J. Sustain. Crop Prod. 3(5):27-30.

15. Mishra V.K., 2000. In vitro antagonism of Trichoderma species against Pythium aphanidermatum, Journal of Phytology 2, pp. 28-35.

16. Manadhar S., Timila R.D. Karkee A., Gupt S.K., Baidya S., 2020. Compatibility study of Trichoderma isolates with chemical fungicides. The Journal of Agriculture and Environment.Vol.21, pp. 9-18.

17. Raiq F., Ishtiq S., 2010. Integrated control of Alternaria solani with Trichoderma spp. and fungicides under in vitro conditions. Sarhad J. Agric. Vol.26, pp. 613-619.

18. Sarkar S., Narayanan P., Divakaran A., 2010. The in vitro effect of certain fungicides, insecticides and biopesticides on mycelial growth in the biocontrol fungus Trichoderma harzianum. Turk J. Biol TÜBITAK, 34: 399-403.

19. Tapwai A., Kumar R., gautam N., Pandey S., 2012.Compatibility of Trichoderma viride for Selected Fungicides and Botanicals. International Journal of Plant Pathology, 3: 89-94.

20. ThoudamR., DutaB.K., 2014. Compatibility of Trichoderma atroviride against black rot disease of tes: an in vitro study. Journal of International Academic Research for Multidisciplinary, Vol. 2, Issue 2, pp.25-33.

21. Wedajo B., 2015. Comapatibility Studies of Fungicides with Combination of Trichoderma Species under In vitro Conditions. Virol-MycolVolume 4, Issue 2:149.

22. Wojtkowiack-Gębarowska, E., Pietr, S.J., 2006. Colonization of roots and growth stimulation of cucumber by iprodione-resistant isolates of Trichoderma spp. applied alone and combined with fungicides. Phytopathologia Polonica, 41, pp. 51-64. 
International Journal of Agriculture, Environment and Bioresearch

Vol. 06, No. 03; 2021

ISSN: 2456-8643

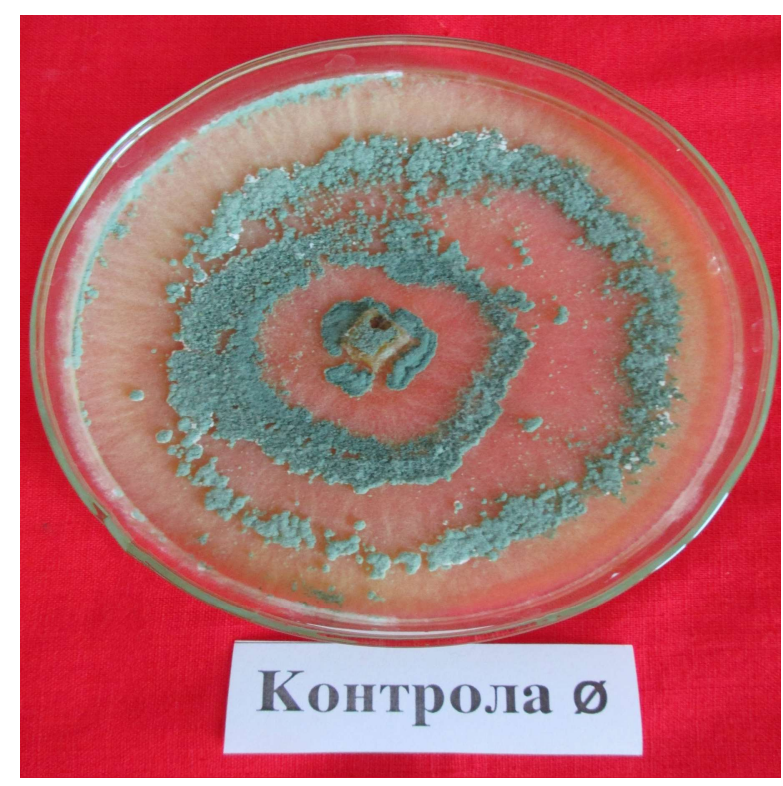

Photo 1- T. harzuanum - (check Ø)
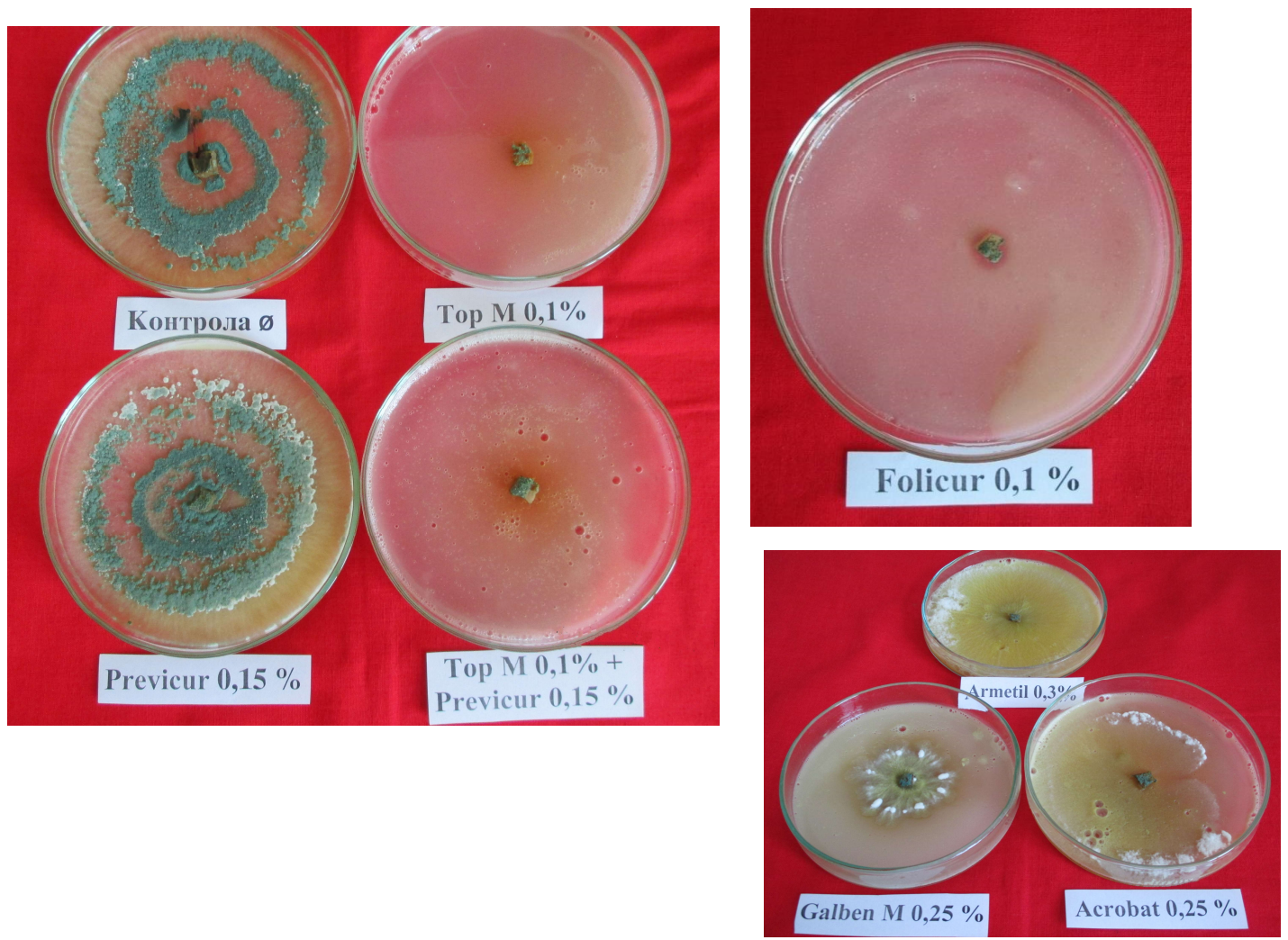
International Journal of Agriculture, Environment and Bioresearch

Vol. 06, No. 03; 2021

ISSN: $2456-8643$
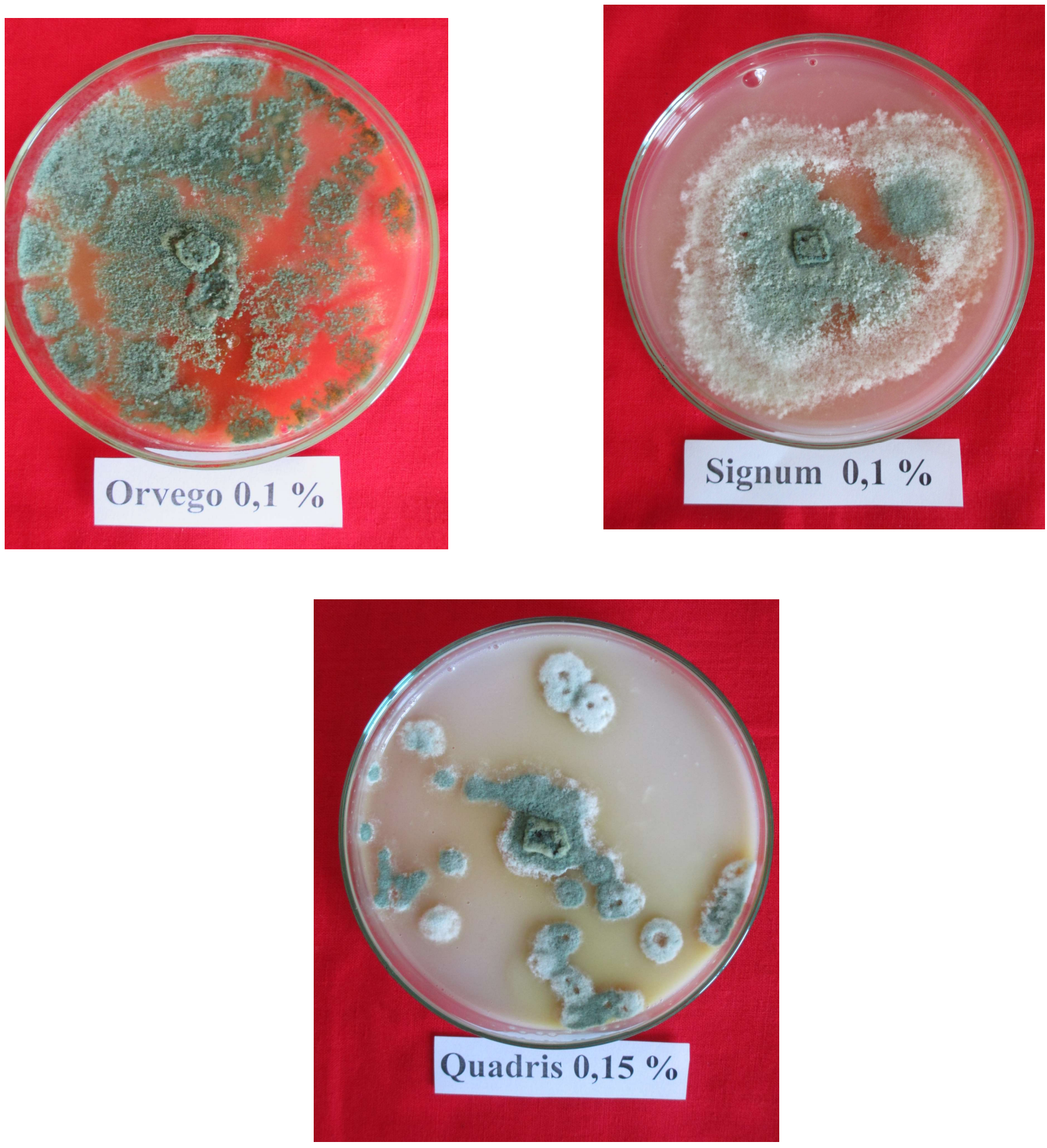

Photo 2-7 Colony of T. harzianumin the presence of fungicides 